\title{
Effect of intravenous preoperative versus postoperative paracetamol on postoperative nausea and vomiting in patients undergoing strabismus surgery: A prospective randomized study
}

\author{
Şaşılık cerrahisi uygulanan hastalarda preoperatif ve postoperatif uygulanan intravenöz \\ parasetamolün postoperatif bulantı ve kusma üzerine etkisi: Bir prospektif randomize çalışma
}

Mehmet AKSOY,' ilker iNCE,' Ali AHISKALIOǦLU,' Sadullah KELEŞ, ${ }^{2}$ Ömer DOYMUŞ'

\begin{abstract}
Summary
Objectives: This prospective randomized study aimed to compare the efficacy of preoperative versus postoperative paracetamol on postoperative nausea and vomiting (PONV) in children undergoing strabismus surgery.

Methods: Ninety-six patients were randomly divided into three equal groups $(n=32)$. In the preoperative paracetamol group, patients received intravenous (IV) infusion of paracetamol [15 mg kg-1 $\left.\left(1.5 \mathrm{ml} \mathrm{kg}^{-1}\right)\right] 1 \mathrm{~h}$ before surgery over $20 \mathrm{~min}$ and that of saline $\left(1.5 \mathrm{ml} \mathrm{kg}^{-1}\right)$ in the recovery room. In the postoperative paracetamol group, patients received IV infusion of saline (1.5 $\mathrm{ml}$ $\left.\mathrm{kg}^{-1}\right) 1 \mathrm{~h}$ before surgery over $20 \mathrm{~min}$ and that of paracetamol $\left[15 \mathrm{mg} \mathrm{kg}^{-1}\left(1.5 \mathrm{ml} \mathrm{kg}^{-1}\right)\right]$ in therecovery room. In the control group, patients received the IV infusion of saline $\left(1.5 \mathrm{ml} \mathrm{kg}^{-1}\right)$ pre- and postoperatively. Postoperative pain condition was evaluated using the Faces Pain Scale. In the recovery room, an observer recorded the pain score, complaints of nausea and vomiting, the need for rescue analgesics, and the need for antiemetic drug during $24 \mathrm{~h}$ postoperatively.

Results: The incidence of nausea and vomiting during the first $0-6 \mathrm{~h}$ postoperatively was significantly lower in the preoperative paracetamol group than in the control and postoperative paracetamol groups $(p<0.001)$. The number of patients requiring antiemetic administration during the first $0-6$ and $6-12 \mathrm{~h}$ postoperatively was found to be higher in the control group than in the other groups $(p<0.001$, for all).
\end{abstract}

Conclusion: The preoperative administration of paracetamol reduces PONV incidence in children undergoing strabismus surgery.

Keywords: Strabismus surgery; paracetamol; postoperative nausea vomiting.

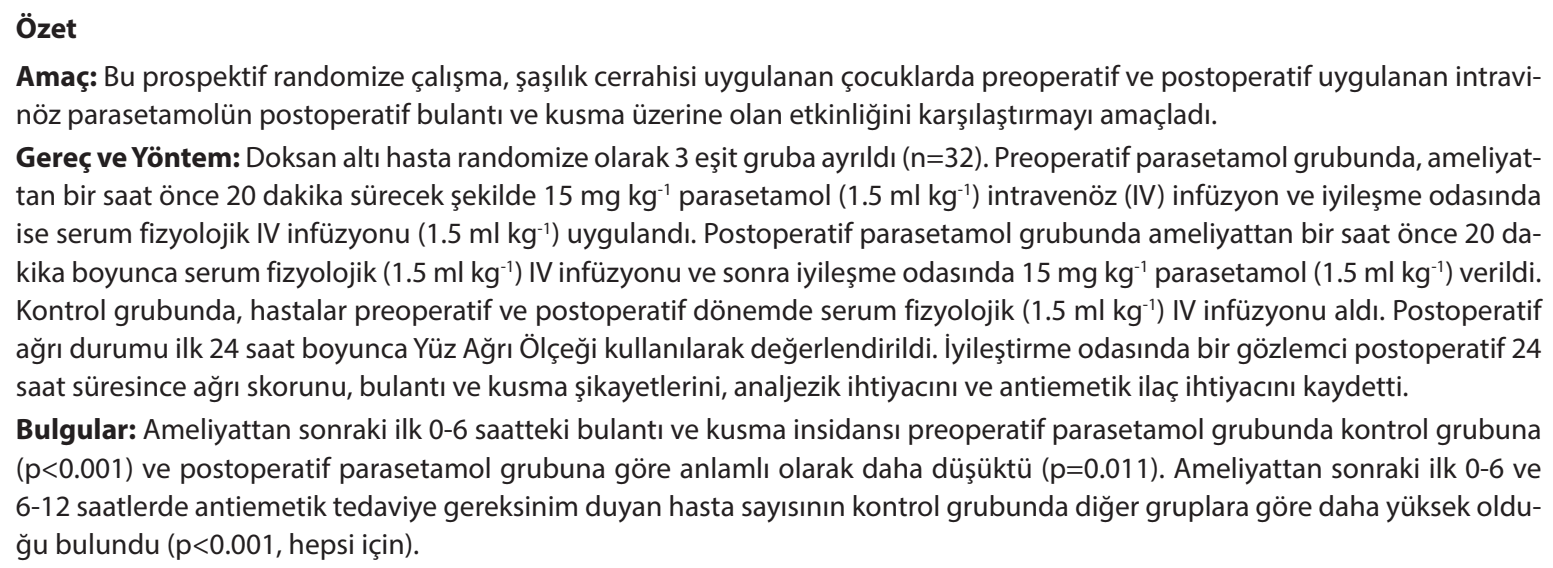

Sonuç: Şaşılık ameliyatı geçiren çocuklarda preoperatif IV parasetamol uygulandığında, postoperatif bulantı ve kusma insidansını azaltmaktadır.

Anahtar sözcükler: Şaşıık cerrahisi; parasetamol; postoperatif bulantı kusma.

\footnotetext{
'Department of Anesthesiology and Reanimation, Ataturk University Faculty of Medicine, Erzurum, Turkey ${ }^{2}$ Department of Ophthalmology, Ataturk University Faculty of Medicine, Erzurum, Turkey
}

Submitted (Başvuru tarihi) 22.01.2017 Accepted after revision (Düzeltme sonrası kabul tarihi) 20.10.2017 Available online date (Online yayımlanma tarihi) 26.01.2018

Correspondence: Dr. Mehmet Aksoy. Atatürk Üniversitesi Tıp Fakültesi, Anestezi ve Reanimasyon Anabilim Dalı, Erzurum, Turkey.

Phone: +90 - 505 - 8193526 e-mail: drmaksoy@hotmail.com

(C) 2018 Turkish Society of Algology 


\section{Introduction}

Strabismus surgery is a common ophthalmic surgical procedure in children. Postoperative nausea and vomiting (PONV) is an undesirable postoperative outcome, occurring in up to $88 \%$ of the patients undergoing strabismus surgery ${ }^{[1]}$ However, the mechanism for the high rate of PONV in these patients remains poorly defined; oculo-emetic reflex, an optokinetic imbalance, and a disturbance of visual axes have been considered responsible for the high incidence of PONV following strabismus surgery. ${ }^{[2,3]}$ PONV causes a delay in the oral intake and extends the duration of hospital stay. ${ }^{[4]}$ Therefore, there have been attempts on using drugs having an antiemetic effect to reduce the incidence of PONV in children after strabismus surgery. ${ }^{[5,6]}$

Paracetamol (acetaminophen; N-acetyl-p-aminophenol) has been well established as a safe and analgesic drug. It has been reported that intravenous (IV) paracetamol is effective and safe for postoperative analgesia in children. ${ }^{[7]}$ However, the mechanism of the analgesic action of paracetamol remains unclear; it inhibits the cyclooxygenase enzyme and activates descending serotonergic inhibitory pathways. ${ }^{[8]}$ Studies have also suggested that paracetamol reduces the incidence of PONV by affecting some serotonergic pathways in the central nervous system. ${ }^{[9,10]}$

We hypothesized that preoperative IV paracetamol is useful in preventing PONV due to strabismus surgery in children. Therefore, we designed a prospective randomized study to compare the efficacy of preoperative versus postoperative paracetamol on PONV in children undergoing strabismus surgery. We also examined the effect of preoperative and postoperative paracetamol administrations on the total analgesic consumption after strabismus surgery.

\section{Material and Methods}

This prospective randomized study was approved by the Ethics Committee of Ataturk University, Medical Faculty, Erzurum, Turkey. This study was performed at the Anesthesiology Clinic of Ataturk University, Medi- cal Faculty, Erzurum, Turkey. Ninety-six patients aged 2-14 years, with ASA (the classification of the American Society of Anesthesiologists) physical status I-II, who underwent elective strabismus surgery under general anesthesia were included. Written informed consent was obtained from the parents. Patients with a history of allergy to any of the study medications (general anesthetic agents or paracetamol); those with a history of previous PONV, hepatic, or renal disease; and those who used antiemetics, antihistaminics, analgesics, or corticosteroids $24 \mathrm{~h}$ prior to surgery were excluded.

Basic data including patients' age, weight, and height were recorded. All patients were pre-medicated with midazolam ( $0.5 \mathrm{mg} \mathrm{kg}^{-1}$, orally) before anesthesia. Before transfer to the operating room, patients were randomly divided into three equal groups $(n=32)$ using a computer generated random number table. In the preoperative paracetamol group $(n=32)$, patients received the IV infusion of paracetamol $\left[15 \mathrm{mg} \mathrm{kg}^{-1}(1.5\right.$ $\left.\mathrm{ml} \mathrm{kg}^{-1}\right)$ ] (Perfalgan ${ }^{\oplus}$, Bristol-Myers Squibb, France) 1 $\mathrm{h}$ before surgery over $20 \mathrm{~min}$ and that of saline (1.5 $\mathrm{ml} \mathrm{kg}^{-1}$ ) in the recovery room after full consciousness. ${ }^{\text {[9] }}$ Patients in the postoperative paracetamol group $(n=32)$ received the IV infusion of saline $\left(1.5 \mathrm{ml} \mathrm{kg}^{-1}\right)$ $1 \mathrm{~h}$ before surgery over $20 \mathrm{~min}$ and paracetamol [15 $\left.\mathrm{mg} \mathrm{kg}^{-1}\left(1.5 \mathrm{ml} \mathrm{kg}^{-1}\right)\right]$ in the recovery room after full consciousness. In the control group ( $n=32)$, patients received the IV infusion of saline $\left(1.5 \mathrm{ml} \mathrm{kg}^{-1}\right)$ pre- and postoperatively (Table 1).

A standardized general anesthesia regimen was provided to all patients. Standard monitoring, including non-invasive arterial pressure, electrocardiography, and pulse oximetry, was established in the operating room. Propofol (2-3 $\left.\mathrm{mg} \mathrm{kg}^{-1}\right)$ and lidocaine $(0.1 \mathrm{mg}$ $\mathrm{kg}^{-1}$ ) were used for general anesthesia, and a laryngeal mask airway (LMA) was inserted. The maintenance of anesthesia was achieved using sevoflurane (2\%-3\%) and $\mathrm{N} 2 \mathrm{O} / \mathrm{O} 2\left(\mathrm{FiO}_{2}, 50 \%\right)$. At the end of the surgery, LMA was removed and patients were transferred to the post-anesthesia recovery room.

Table 1. Study groups

\begin{tabular}{lccc}
\hline & $\begin{array}{c}\text { Preoperative paracetamol } \\
\text { group }\end{array}$ & $\begin{array}{c}\text { Postoperative paracetamol } \\
\text { group }\end{array}$ & Control group \\
\hline $1 \mathrm{~h}$ before surgery & $\mathrm{IV}$ paracetamol $\left(1.5 \mathrm{ml} \mathrm{kg}^{-1}\right)$ & $\mathrm{IV}$ saline $\left(1.5 \mathrm{ml} \mathrm{kg}^{-1}\right)$ & $\mathrm{IV} \mathrm{saline}\left(1.5 \mathrm{ml} \mathrm{kg}{ }^{-1}\right)$ \\
In the recovery room & $\mathrm{IV}$ saline $\left(1.5 \mathrm{ml} \mathrm{kg}^{-1}\right)$ & $\mathrm{IV}$ paracetamol $\left(1.5 \mathrm{ml} \mathrm{kg}^{-1}\right)$ & $\mathrm{IV} \mathrm{saline}\left(1.5 \mathrm{ml} \mathrm{kg} \mathrm{kg}^{-1}\right)$
\end{tabular}


Oculocardiac reflex (OCR) was defined as an acute decrease $(\geq 30 \%)$ in the heart rate associated with traction on eye muscle. Atropine $(0.01 \mathrm{mg} / \mathrm{kg})$ was administered via IV in case the heart rate did not return to baseline following the release of muscle traction. The number of orbital muscles requiring surgery, duration of anesthesia, duration of surgery, and the number of patients who experienced OCR requiring treatment with atropine were recorded.

The primary outcome for this study was the incidence of nausea and vomiting during the first $24 \mathrm{~h}$ postoperatively, and the secondary outcome was the need for rescue analgesics and for antiemetic drug during $24 \mathrm{~h}$ postoperatively. In the recovery room, an independent observer blinded to the group assignment recorded the pain score, complaints of nausea and vomiting, the need for rescue analgesics, and the need for antiemetic drug during $24 \mathrm{~h}$ postoperatively. Nausea was defined as retching alone, and vomiting was defined as a forceful expulsion of gastric contents through the mouth or the nose. [9] Intravenous metoclopramide [0.15 $\mathrm{mg} \mathrm{kg}^{-1}$; maximum, $0.5 \mathrm{mg} \mathrm{kg}^{-1}$ day $^{-1}$ ] was administered in case of two or more vomiting episodes.

The postoperative pain condition was evaluated using the Faces Pain Scale every hour starting from when the patients were awake from arrival in the recovery room to $24 \mathrm{~h}$ postoperatively. ${ }^{[11]}$ This scale includes six faces reflecting the severity of pain, and every facial expression has a numerical score. The selected face by children or their parents and the numerical score of selected face was recorded. In all groups, postoperative analgesia was provided with oral ibuprofen suspension (Ibufen ${ }^{\circledast}$, Abbott, Istanbul, Turkey) [5 mg kg${ }^{-1}$; maximum, $40 \mathrm{mg} \mathrm{kg}^{-1}$ day $^{-1}$ ] for a Faces Pain Scale score of $\geq 3$.

The primary endpoint of the study was the incidence of nausea and vomiting during the first $24 \mathrm{~h}$ postoperatively. The minimum sample size required for this study was calculated based on the Cok et al.'s study ${ }^{[9]}$ using the Russ Lenth's Power and sample size calculation application. ${ }^{[12]}$ Thirty patients in each group were needed to demonstrate a mean difference of $20 \%$ for the incidence of nausea between two study groups with a power of $80 \%$ and alpha $5 \%$.
Data were analyzed using SPSS software 12.0 (SPSS Inc., Chicago, IL, USA) and calculated as mean \pm standard deviation or number (\%). $\mathrm{P}<0.05$ was considered significant. Distribution of data was assessed using the Kolmogorov-Smirnov test. Comparisons among the groups were performed with one-way ANOVA test. Fisher's exact test was used to compare percentage values.

\section{Results}

Eligible patients for this study were analyzed in the CONSORT flow diagram (Fig. 1). ${ }^{[13]}$ During the study period, 120 patients were eligible for this study and 110 met the inclusion criteria. Ninety-six children and their parents agreed to participate and were enrolled and randomly assigned into three groups $(n=32$ each). Six patients were excluded because they were discharged from the hospital within the first $12 \mathrm{~h}$ postoperatively. Eventually, the data from 90 patients were analyzed.

Baseline patients' characteristics are shown in Table 2. There were no statistically significant differences among the groups regarding sex, age, weight, height, ASA status, the number of patients who experienced $\mathrm{OCR}$, the number of muscles operated, the duration of anesthesia, and the duration of surgery $(p>0.05)$.

There were no statistically significant differences among the study groups with respect to the mean pain scores during the first $0-6,6-12$, and $12-24 \mathrm{~h}$ postoperatively (Table 3). As shown in Table 4, the incidence of nausea during the first 0-6 h postoperatively was significantly lower in the preoperative

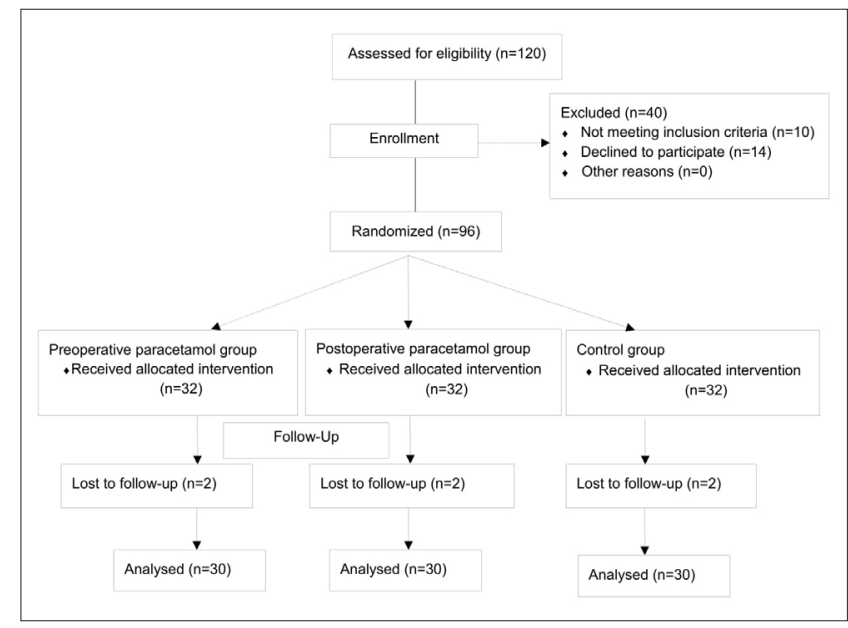

Figure 1. CONSORT flow diagram. The course of patients through this study was shown. 
paracetamol group than in the control $(p<0.001)$ and postoperative paracetamol $(p=0.011)$ groups. Control group had a higher incidence of nausea during the first $6-12 \mathrm{~h}$ postoperatively than the preoperative and postoperative paracetamol groups $(p<0.001$, for both). Also, the incidence of postoperative vomiting during the first 0-6 $\mathrm{h}$ was significantly lower in the preoperative paracetamol group than in the control and postoperative paracetamol groups ( $p<0.001$, for both groups) (Table 4). During the first $0-6 \mathrm{~h}$ postoperatively, 12 (40\%) patients required oral ibuprofen administration in the control group, while six (20\%) in the preoperative paracetamol group and four $(13.3 \%)$ in the postoperative paracetamol group re-

Table 2. Demographic and operation characteristics of patients

\begin{tabular}{lcccc}
\hline & $\begin{array}{c}\text { Preoperative } \\
\text { paracetamol group } \\
(\mathbf{n = 3 0 )}\end{array}$ & $\begin{array}{c}\text { Postoperative } \\
\text { paracetamol group } \\
(\mathbf{n = 3 0 )}\end{array}$ & $\begin{array}{c}\text { Control group } \\
(\mathbf{n = 3 0})\end{array}$ \\
\hline Age (year) & $9.13 \pm 4.24$ & $7.66 \pm 3.56$ & $9.13 \pm 3.57$ & 0.233 \\
Weight (kg) & $30.50 \pm 13.12$ & $25.00 \pm 10.71$ & $28.43 \pm 13.41$ & 0.232 \\
Sex (male/female) & $19 / 11$ & $16 / 14$ & $18 / 12$ & 0.732 \\
ASA I/II & $25 / 5$ & $26 / 4$ & $23 / 7$ & 0.756 \\
Duration of surgery (min) & $78.96 \pm 9.91$ & $78.33 \pm 9.49$ & $81.33 \pm 11.05$ & 0.488 \\
Number of muscles (1/2) & $10 / 20$ & $8 / 22$ & $6 / 24$ & 0.858 \\
Patients who experienced OCR (n) & 2 & 3 & 2 & 0.861 \\
\hline
\end{tabular}

OCR: oculocardiac reflex.

Table 3. Mean pain scores of groups during $24 \mathrm{~h}$ postoperatively

\begin{tabular}{lcccc}
\hline & $\begin{array}{c}\text { Preoperative } \\
\text { paracetamol group } \\
(\mathbf{n}=\mathbf{3 0})\end{array}$ & $\begin{array}{c}\text { Postoperative } \\
\text { paracetamol group } \\
(\mathbf{n}=\mathbf{3 0})\end{array}$ & $\begin{array}{c}\text { Control group } \\
(\mathbf{n}=\mathbf{3 0})\end{array}$ \\
\hline $0-6 \mathrm{~h}$ & $2.43 \pm 1.04$ & $2.73 \pm 0.94$ & & $\mathbf{p}$ \\
$6-12 \mathrm{~h}$ & $1.30 \pm 0.79$ & $1.20 \pm 0.66$ & $2.70 \pm 0.91$ & 0.424 \\
$12-24 \mathrm{~h}$ & $0.66 \pm 0.66$ & $0.26 \pm 0.58$ & $1.53 \pm 0.73$ & 0.200 \\
& & & $0.53 \pm 0.81$ & 0.082
\end{tabular}

Table 4. Incidence of nausea and vomiting in the groups

\begin{tabular}{|c|c|c|c|}
\hline & $\begin{array}{c}\text { Preoperative } \\
\text { paracetamol group } \\
(n=30)\end{array}$ & $\begin{array}{c}\text { Postoperative } \\
\text { paracetamol group } \\
(n=30)\end{array}$ & $\begin{array}{l}\text { Control } \\
\text { group } \\
(n=30)\end{array}$ \\
\hline \multicolumn{4}{|l|}{ Nausea n (\%) } \\
\hline $0-6 \mathrm{~h}$ & $3(10)$ & $12(40)^{*}$ & $16(53)^{* *}$ \\
\hline $6-12 \mathrm{~h}$ & $2(6.66)^{a}$ & $1(3.33)^{a}$ & $12(40)$ \\
\hline $12-24 \mathrm{~h}$ & $3(10)$ & $4(13.3)$ & $3(10)$ \\
\hline \multicolumn{4}{|c|}{ Vomiting n (\%) } \\
\hline $0-6 \mathrm{~h}$ & $2(6.6)^{a}$ & $8(26.6)$ & $14(46.6)$ \\
\hline $6-12 \mathrm{~h}$ & $3(10)$ & $3(10)$ & $5(16.6)$ \\
\hline $12-24 \mathrm{~h}$ & $1(3.3)$ & $2(6.6)$ & $4(13.3)$ \\
\hline
\end{tabular}

${ }^{*}: p=0.011 ; * *: p<0.001$, compared with preoperative paracetamol group; ${ }^{a}: p<0.001$, compared with control group. 
Table 5. Need for rescue analgesics and antiemetic drug in patients during $24 \mathrm{~h}$ postoperatively

\begin{tabular}{|c|c|c|c|}
\hline & $\begin{array}{c}\text { Preoperative } \\
\text { paracetamol group } \\
\qquad(n=30)\end{array}$ & $\begin{array}{c}\text { Postoperative } \\
\text { paracetamol group } \\
\qquad(n=30)\end{array}$ & $\begin{array}{l}\text { Control group } \\
\qquad(n=30)\end{array}$ \\
\hline \multicolumn{4}{|c|}{$\begin{array}{l}\text { Number of patients } \\
\text { requiring rescue } \\
\text { analgesia } \mathrm{n}(\%)\end{array}$} \\
\hline $0-6 \mathrm{~h}$ & $6(20)^{*}$ & $4(13.3)^{* *}$ & $12(40)$ \\
\hline $6-12 \mathrm{~h}$ & 0 & 0 & 0 \\
\hline $12-24 \mathrm{~h}$ & 0 & 0 & 0 \\
\hline \multicolumn{4}{|c|}{$\begin{array}{l}\text { Number of patients } \\
\text { requiring antiemetic n (\%) }\end{array}$} \\
\hline $0-6 \mathrm{~h}$ & $3(10)^{\beta}$ & $11(36)^{* *, a}$ & $22(73.3)$ \\
\hline $6-12 \mathrm{~h}$ & $2(6.6)^{\beta}$ & $3(10)^{\beta}$ & $13(43.3)$ \\
\hline $12-24 \mathrm{~h}$ & $1(3.3)$ & $2(6.6)$ & $4(13.3)$ \\
\hline
\end{tabular}

${ }^{*} \mathrm{p}=0.008 ;{ }^{* *} \mathrm{p}=0.001 ;{ }^{\beta} \mathrm{p}<0.001$; compared with control group. ${ }^{a} \mathrm{p}=0.017$; compared with preoperative paracetamol group.

quired analgesic administration $(\mathrm{p}=0.008, \mathrm{p}=0.001$; respectively) (Table 5). None of the patients in any group required rescue analgesics during the first 6-12 and 12-24 h postoperatively. The number of patients requiring antiemetic administration during the first $0-6$ and $6-12 \mathrm{~h}$ postoperatively was found to be higher in the control group than in the preoperative and postoperative paracetamol groups $(p<0.001$, for all). There are no differences among the groups in terms of antiemetic administration during 12-24 $\mathrm{h}$ postoperatively (Table 5 ).

\section{Discussion}

This prospective, randomized study was designed to evaluate the efficacy of IV preoperative and postoperative paracetamol administrations for the prevention of PONV in children undergoing strabismus surgery. The incidence of PONV during the first $6 \mathrm{~h}$ after surgery was significantly reduced in the preoperative paracetamol group than in the postoperative paracetamol and control groups. Also, the incidence of PONV was not significantly different in the preoperative and postoperative paracetamol groups during the first 6-12 and 12-24 h postoperatively.

Previous studies have demonstrated the effect of reducing postoperative pain following the use of preoperative paracetamol in different surgeries. ${ }^{[10,}$ ${ }^{14]}$ Some studies have also revealed the antiemetic effect of IV paracetamol administration following surgery. ${ }^{[9,}{ }^{10]}$ However, our study is the first to compare the effect of preoperative and postoperative IV paracetamol administrations on PONV in children undergoing strabismus surgery.

The incidence of PONV has been reported to be approximately $40 \%-88 \%$ in patients undergoing strabismus surgery without antiemetic prophylaxis. ${ }^{[1,5}$, 9] Researchers have suggested that the intraoperative tension on ocular muscles provokes a vagal response (oculocardiac reflex), which causes PONV. ${ }^{[2,3]}$ Also, the reduction in the incidence of nausea was found to be correlated with the reduction of pain. ${ }^{[15]}$ Extreme retching or vomiting in the early postoperative period leads to prolonged recovery, an increased risk of bleeding, tension in surgical sutures, and an increased risk of pulmonary aspiration. ${ }^{[16]}$ Drugs with antiemetic activity (e.g., metoclopramide and ondansetron), anesthesia techniques reducing postoperative pain (e.g., subtenon's or peribulbar blocks and topical NSAIDS), and analgesics (e.g., opioids, NSAIDS, and paracetamol) were recommended to reduce $P O N V$ in children undergoing strabismus surgery. ${ }^{[17,18]}$ In our study, the pain scores were similar among the three groups during the first $24 \mathrm{~h}$ following surgery; however, the incidence of nausea and vomiting during the first $0-6 \mathrm{~h}$ postoperatively was lower in patients in the preoperative and postoperative paracetamol groups than in those in the control group. Therefore, we suggested that sufficient an- 
algesia was provided in the first $24 \mathrm{~h}$ in all groups. Thus, the reduction in the incidence of nausea and vomiting during the first $0-6 \mathrm{~h}$ postoperatively in the preoperative and postoperative paracetamol groups may be related to the antiemetic effect of paracetamol rather than pain reduction.

Studies in children have shown that IV paracetamol improves the quality of postoperative analgesia. ${ }^{[19,20]}$ A systematic meta-analysis has revealed that IV acetaminophen reduces nausea when prophylactically administered either before surgery or before arrival in the post-anesthesia care unit; but not when administered after the onset of pain. ${ }^{[15]}$ Consistent with these results; the incidence of nausea and vomiting during the first $0-6 \mathrm{~h}$ postoperatively was found to be lower in patients who received preoperative paracetamol than in those who received postoperative paracetamol in our study. Chemoreceptor trigger zone includes dopamine, opioid, and serotonin 5-HT3 receptors and receptor antagonists (e.g., ondansetron and granisetron), which are used for the prevention and treatment of PONV. ${ }^{[21]}$ Cok et al. ${ }^{[9]}$ have reported that the intraoperative administration of IV paracetamol decreases the incidence of PONV during the first $24 \mathrm{~h}$ in children after strabismus surgery. Despite unclear mechanisms of analgesic and antiemetic actions of paracetamol, studies have shown that paracetamol inhibits the cyclooxygenase enzyme and affects some serotonergic pathways in the central nervous system. ${ }^{[8,22]}$ Serotonin is found in the brainstem vomiting center. AM404 (a metabolization product of paracetamol in the brain) inhibits the reuptake of anandamide. ${ }^{[23]}$ Decreased anandamide levels were found to be associated with a high incidence of nausea and vomiting in humans. ${ }^{[24]}$ This may be another explanation for the antiemetic effect of acetaminophen.

It is suggested that an altered visual perception and afferent impulses causing reflex are responsible for PONV after strabismus surgery. Also, the number of ocular muscles that are repaired was reported to be associated with an increased risk of PONV ${ }^{[16]}$ In our study, the groups were comparable with respect to patient characteristics including the number of patients who experienced OCR, the number of muscles operated, and the surgical procedure.

\section{Limitations}

The relatively small population is a limitation of this study. Studies with a larger sample are needed to evaluate the effect of preoperative paracetamol on the incidence of PONV.

\section{Conclusion}

The use of IV preoperative paracetamol reduces the incidence of PONV and postoperative antiemetic consumption during the first $6 \mathrm{~h}$ after strabismus surgery. Therefore, preoperative IV paracetamol reduces the incidence of PONV in children undergoing strabismus surgery. Further studies are necessary to prove the effectiveness of preoperative paracetamol in reducing the incidence of PONV among children after strabismus surgery.

\section{Conflict-of-interest issues regarding the authorship or} article: None declared.

\section{Peer-rewiew: Externally peer-reviewed.}

\section{References}

1. Klockgether-Radke A, Neumann S, Neumann P, Braun U, Mühlendyck $\mathrm{H}$. Ondansetron, droperidol and their combination for the prevention of post-operative vomiting in children. Eur J Anaesthesiol 1997;14(4):362-7. [CrossRef]

2. van den Berg AA, Lambourne A, Clyburn PA. The oculoemetic reflex. A rationalisation of postophthalmic anaesthesia vomiting. Anaesthesia 1989;44(2):110-7.

3. Kaufman S, Martin-Sheridan D. Postoperative nausea and vomiting after strabismus surgery: mechanisms, treatment, and implications for practice. CRNA 1996;7(3):139-43.

4. Elder M, Steven D, Beasley S, Wium D. Unplanned overnight hospital admission after strabismus surgery. N Z Med J 2007;120(1260):U2681.

5. Ebrahim Soltani AR, Mohammadinasab $H$, Goudarzi $M$, Arbabi S, Mohammadinasab A, Mohammadinasab F, et al. Comparing the efficacy of prophylactic p6 acupressure, ondansetron, metoclopramide and placebo in the prevention of vomiting and nausea after strabismus surgery. Acta Med Iran 2011;49(4):208-12.

6. Bicer C, Aksu R, Ulgey A, Madenoglu H, Dogan H, Yildiz K, et al. Different doses of palonosetron for the prevention of postoperative nausea and vomiting in children undergoing strabismus surgery. Drugs R D 2011;11(1):29-36. [CrossRef]

7. Shastri N. Intravenous acetaminophen use in pediatrics. Pediatr Emerg Care 2015;31(6):444-8; quiz 449-50. [CrossRef]

8. Pickering G, Loriot MA, Libert F, Eschalier A, Beaune P, Dubray $C$. Analgesic effect of acetaminophen in humans: first evidence of a central serotonergic mechanism. Clin Pharmacol Ther 2006;79(4):371-8. [CrossRef]

9. Cok OY, Eker HE, Pelit A, Canturk S, Akin S, Aribogan A, et al. The effect of paracetamol on postoperative nausea and 
vomiting during the first $24 \mathrm{~h}$ after strabismus surgery: a prospective, randomised, double-blind study. Eur J Anaesthesiol 2011;28(12):836-41. [CrossRef]

10. Unal SS, Aksoy M, Ahiskalioglu A, Erdem AF, Adanur S. The effect of intravenous preemptive paracetamol on postoperative fentanyl consumption in patients undergoing open nephrectomy: a prospective randomized study. $\mathrm{Ni}$ ger J Clin Pract 2015;18(1):68-74.

11. Wong DL, Baker CM. Pain in children: comparison of assessment scales. Pediatr Nurs 1988;14(1):9-17.

12. Lenth RV. Java Applets for Power and Sample Size [Computer software] 2006. Available at: http://www.stat.uiowa. edu/ rlenth/Power. Accessed Apr 14, 2016.

13. Schulz KF, Altman DG, Moher D; CONSORT Group. CONSORT 2010 statement: updated guidelines for reporting parallel group randomised trials. Int J Surg 2011;9(8):672-7. [CrossRef]

14. Arici S, Gurbet A, Türker G, Yavaşcaoğlu B, Sahin S. Preemptive analgesic effects of intravenous paracetamol in total abdominal hysterectomy. Agri 2009;21(2):54-61.

15. Apfel CC, Turan A, Souza K, Pergolizzi J, Hornuss C. Intravenous acetaminophen reduces postoperative nausea and vomiting: a systematic review and meta-analysis. Pain 2013;154(5):677-89. [CrossRef]

16. Awad IT, Moore M, Rushe C, Elburki A, O'Brien K, Warde D. Unplanned hospital admission in children undergoing day-case surgery. Eur J Anaesthesiol 2004;21(5):379-83.
17. Kovac AL. Management of postoperative nausea and vomiting in children. Paediatr Drugs 2007;9(1):47-69. [CrossRef]

18. Howard R, Carter B, Curry J, Morton N, Rivett K, Rose M, et al; Association of Paediatric Anaesthetists of Great Britain and Ireland. Postoperative pain. Paediatr Anaesth 2008;18 Suppl 1:36-63. [CrossRef]

19. Uysal HY, Takmaz SA, Yaman F, Baltaci B, Başar H. The efficacy of intravenous paracetamol versus tramadol for postoperative analgesia after adenotonsillectomy in children. J Clin Anesth 2011;23(1):53-7. [CrossRef]

20. Alhashemi JA, Daghistani MF. Effects of intraoperative i.v. acetaminophen vs i.m. meperidine on post-tonsillectomy pain in children. Br J Anaesth 2006;96(6):790-5. [CrossRef]

21. Loewen PS, Marra CA, Zed PJ. 5-HT3 receptor antagonists vs traditional agents for the prophylaxis of postoperative nausea and vomiting. Can J Anaesth 2000;47(10):1008-18.

22. Graham GG, Scott KF. Mechanism of action of paracetamol. Am J Ther 2005;12(1):46-55. [CrossRef]

23. Högestätt ED, Jönsson BA, Ermund A, Andersson DA, Björk $\mathrm{H}$, Alexander JP, et al. Conversion of acetaminophen to the bioactive N-acylphenolamine AM404 via fatty acid amide hydrolase-dependent arachidonic acid conjugation in the nervous system. J Biol Chem 2005;280(36):31405-12.

24. Sharkey KA, Darmani NA, Parker LA. Regulation of nausea and vomiting by cannabinoids and the endocannabinoid system. Eur J Pharmacol 2014;722:134-46. [CrossRef] 